\title{
STUDI KRITIS TERHADAP PEMIKIRAN MAHMUD MUHAMMAD TAHA TENTANG KONSEP NASAKH AL-QUR'AN
}

\author{
Muhammad Al Fikri \\ UIN Sulthan Thaha Saifuddin Jambi \\ Email: fikri@uinjambi.ac.id
}

\author{
Ahmad Mustaniruddin \\ UIN Sulthan Thaha Saifuddin Jambi \\ Email:ahmad_mustanirruddin@uinjambi.ac.id
}

\begin{abstract}
This article discusses one of the topics of the study of the Qur'anic science which was developed by one of the contemporary thinkers, namely Mahmud Muhammad Taha. He considered that the Islamic teachings contained in the madaniyah verses were irrelevant at this time because they contained values that were less tolerant and even radical. Meanwhile, the Makiyah verses contain fundamental values such as justice, equality, tolerance, democracy, and human rights. So, according to him, madaniyah verses need to be replaced with these makiyah verses. With such an inverted nasakh concept, he wants to carry out an evolution of sharia where according to him sharia is something historical that can change according to the situation and conditions that require it. The concept of nasakh al-Qur'an developed by Taha is different from the concept of nasakh agreed upon by the majority of scholars. Therefore, based on the critical analysis in this article, it can be said that the nasakh Taha concept still has a number of epistemological problems so that it is not valid for use in interpreting the verses of the Qur'an.
\end{abstract}

Keywords: Mahmud Muhammad Taha, Makki-Madani, Nasakh

\begin{abstract}
Abstrak
Artikel ini mendiskusikan tentang topik kajian ilmu al-Qur'an yang dikembangkan oleh salah satu tokoh pemikir kontemporer yaitu Mahmud Muhammad Taha. Ia menilai bahwa ajaran Islam yang terkandung dalam ayat-ayat madaniyah tidak Sesuai dengan nilai - nilai kemanuasiaan dan masyarakat modern karena ayat madaniyah mengandung nilai radikalisme dan berlawanan dengan hak asasi manusia.
\end{abstract}


Sementara ayat-ayat makiyah berisi tentang nilai-nilai fundamental seperti keadilan, kesetaraan, toleransi, demokrasi, dan HAM. Sehingga, menurutnya, ayat-ayat madaniyah perlu di-nasakh dengan ayat-ayat makiyah tersebut. Dengan konsep nasakh terbalik seperti demikian ia ingin melakukan evolusi terhadap syariat di mana menurutnya syariat merupakan sesuatu yang bersifat historis yang dapat berubah sesuai situasi dan kondisi yang menghendakinya. Konsep nasakh al-Qur'an yang dikembangkan oleh Taha tersebut berbeda dengan konsep nasakh yang disepakati oleh mayoritas ulama. Oleh karena itu, berdasarkan analisis kritis dalam artikel ini dapat dikatakan bahwa konsep nasakh Taha tersebut masih terdapat sejumlah permasalahan epistemologis sehingga tidak valid untuk digunakan dalam penafsiran al-Qur'an.

Kata Kunci: Mahmud Muhammad Taha, Makki-Madani, Nasakh

\section{Pendahuluan}

Islam Merupakan agama pembawa rahmat dan kedamaian bagi umat manusia. al-Qur'an merupakan pedoman untuk umat manusia yang relevan sepanjang masa dan di mana saja (shalih li kulli zaman wa makan). Dua adagium tersebut seringkali-dan memang seharusnya-dijadikan sebagai dasar untuk menjelaskan bahwa Islam adalah agama yang menjunjung tinggi nilai-nilai universal, inklusif, dan tidak menolak modernitas. Kendati demikian, Islam tidak luput pula digambarkan sebagai agama yang ekslusif, rigid, bahkan ekstrim oleh sementara orang. Anggapan itu tidak dapat pula dipungkiri karena memang terdapat sejumlah orang Islam yang cenderung memahami agamanya secara literal melalui teks al-Qur'an maupun hadis. Di tangan mereka, Islam seakan lepas dari konteks di mana dan kapan ia lahir serta konteks di mana dan kapan ia diterapkan.

Selain persoalan literalisme, kejumudan Islam juga difaktori oleh doktrin bahwa pintu ijtihad telah ditutup sehingga pemikiranpemikiran progresif dianggap menyimpang dan sesat. Salah satu tokoh pemikir Islam kontemporer yang dihukumi sesat bahkan murtad adalah Mahmud Muhammad Taha. Pasalnya, ia mengembangkan pemahaman atau pandangan tentang Islam yang bertentangan dengan pemahaman yang telah mapan di kalangan 
para tradisionalis. Dalam gagasannya tentang Syariat Modern, misalnya, Taha meyatakan bahwa syariat terus berkembang dan terikat oleh ruang dan waktu sesuai dengan perkembangan pemikiran dan peradaban manusia. Ini menunjukkan syariat tersbut mengalami perkembangan secara terus menerus seiring kemajuan pemikiran dan peradaban manusia. ${ }^{1}$

Dalam konteks tersebut, Taha merekonstruksi konsep nasakh al-Qur'an yang telah mapan dalam khazanah keilmuan Islam. Konsep nasakh yang selama ini dipahami adalah mengganti hukum yang telah ditetapkan sebelumnya dengan hukum datang belakangan. Yang dimaksud mengganti hukum adalah hilangnya hukum tersebut dan memberikan kemudahan dalam pelaksanaannya. ${ }^{2}$ Namun, konsep nasakh al-Qur'an tidak lepas dari diskursus tentang makki dan madani. Taha memberikan pandangan baru dalam persoalan ini. Ia membagi Islam pada dua periode, yaitu periode Makkah yang disebut dengan al-Risalah al-Ula dan periode Madinah yang disebut dengan al-Risalab al-Tsaniyah. Adapun karakteristik Islam yang ada pada periode Makkah banyak didominasi oleh ajaran-ajaran bernuansa akidah, universal, subtantif dan bercirikan sifat demokratis, sedangkan Islam pada periode kedua sudah menjadi bangunan keislaman yang cenderung mapan dan penuh dengan hukum-hukum syariat. ${ }^{3}$

Oleh karena itu, menurut Taha Masyarakat wajib memakai ayat Makkiyah dan menghapus ayat-ayat madaniyah. Karena Ayat makiyah cenderung sesuai di era modern, dimana ayat makiyah merupakan ayat Utama yang membawa ke universalan islam, yang menekankan nilai-nilai keadilan, gender, tanpa membedakan jenis kelamin, epercayaan agama, ras, serta yang lain. Sedangkan ayat

1 Abdul Mustaqim, Dkk, Melihat Kembali Studi Al-Qur'an: Gagasan, Isu Dan Tren Terkini (Yogyakarta: Idea Press, 2015), p. 22.

2 Manna' Al-Qaththan, Mabahits Fi 'Ulum Al-Qur'an (Beirut: Dar al-Fikr, 1990), p. 232.

3 Abdullah Ahmad An-Naim, Dekonstruksi Syari'ab: Wacana Kebebasan Sipil, Hak Asasi Manusia Dan Hubungan Internasional Dalam Islam, trans. by Amiruddin Arrani Ahmad Suaedy (Yogyakarta: LKiS, 2012), p. 7. 
madaniyah merupakan ayat- ayat cabang( furu) yang berlaku cocok dengan keadaan serta keahlian umat Islam waktu itu. Bila sepanjang ini syariat lebih banyak didasarkan pada ayat- ayat madaniyah, perihal tersebut tidak bisa dipertahankan lagi, sebab suasana serta keadaan dikala ini berbeda dengan keadaan pada abad ke- $7 \mathrm{H}^{4}$

Dalam pemikiran Taha, syariat modern pada dasarnya hanya perpindahan dari ayat- ayat madaniyah ke ayat- ayat makiyah. Bersumber pada pemikiran tersebut, Taha setelah itu melahirkan isu kebebasan serta persamaan pria serta wanita, dan muslim serta non- muslim. Taha berupaya membalik konsep nasakh yang sudah mapan di golongan tradisionalis. Bila sepanjang ini para ulama biasanya mengatakan kalau ayat- ayat madaniyah itu yang menasakh ayat- ayat makiyah, hingga tidak demikian dengan konsep nasakh yang digagas oleh Mahmud Muhammad Taha. Baginya, malah ayat- ayat makiyah seperti itu yang me- nasakh ayat- ayat madaniyah. Menurutnya nasakh cuma hanya penghapusan hukum secara terbatas serta temporal sehingga boleh jadi ayat- ayat umum makiyah yang sudah dihapus oleh ayat- ayat partikular madaniyah pada abad ke- 7 dapat diaplikasikan kembali pada abad ke-20 ini. ${ }^{5}$

Taha dalam bukunya memandang ketika Islam (al-Qur'an) masih dipahami sebagaimana pemahaman salaf maka Islam akan ketinggalan bahkan tidak sesuai pada hak asasi manusia yang selanjutnya berimplikasi pada hukum publik. Upaya untuk memberlakukan lagi hukum ayat ayat makiyah dan menangguhkan hukum pada ayat-ayat madaniyah adalah sifat dan karakteristik yang terkandung dalam masing-masing ayat. Bahwa ayat-ayat makiyah lebih manusiawi dan universal serta mendukung hak asasi manusia dibanding dengan ayat madaniyah yang banyak mengandung unsur sektarian dan persamaan gender antara

\footnotetext{
${ }^{4}$ Mustaqim, Dkk, p. 22.

${ }^{5}$ Mustaqim, Dkk, p. 22.
} 
individu yang satu dengan yang lain terutama antara kaum perempuan dan laki-laki. ${ }^{6}$

Ide tersebut cukup menggemparkan dunia serta melahirkan gelombang respon yang luar biasa sebab sudah melanggar apa yang jadi kesepakatan seluruh ulama, sepanjang ini kalau nasakh bertabiat abadi serta tidak dapat diintervensi tangan manusia. Pemikirannya tentang nasakh pula menghancurkan paradigma yang telah terbangun begitu mapan kalau ayat yang turun belum lama( madaniyah) me- nasakh ayat- ayat yang turun lebih dulu( makiyah), serta kalau nasakh sudah berakhir pasca wafatnya Rasulullah saw. ${ }^{7}$

Berdasarkan uraian di atas maka fokus penelitian penulis adalah mengkaji konsep nasakh menurut Mahmud Muhammad Taha dan pengaruhnya pada nasakh al-Qur'an terutama terhadap ayat-ayat madaniyah yang tidak relevan lagi menurutnya. Penelitian ini juga tidak hanya mendeskripsikan konsep Taha, tetapi juga menganalisis tolok ukur kebenaran konsep yang ditawarkannya secara kritis. Dengan demikian, penulis menggunakan metode penelitian kualitatif dengan analisis isi (content analysis) sebagai pendekatannya.

\section{Biografi Intelektual Taha}

Mahmud Muhammad Taha (selanjutya disebut Taha) merupakan seorang intelektual Islam kontemporer asal Sudan. Mahmud Muhammad Taha dilahirkan pada tahun 1909 di daerah Rufa'ah yaitu kota kecil di tepi timur Blue Nile, Sudan Tengah. Taha kecil menghabiskan waktunya sebagai anak yatim piatu dan diasuh oleh keluarga jauh nya. Ibunya meninggal dunia pada tahun

${ }^{6}$ Mustaqim, Dkk, p. 76.

${ }^{7}$ Wahbah Zuhaili, Ushul Al-Fiqh Al-Islami (Beirut: Dar al-Fikr, 2001), II, p. 959. 
1915 sedangkan ayahnya meninggal dunia lima tahun kemudian yaitu pada tahun $1920 .^{8}$

Taha kecil memulai pendidikannya di sebuah langgar kecil yang biasa disebut dengan Khalwah yaitu tempat di mana anakanak menghafal al-Qur'an dan mempelajari kaidah-kaidah dasar bahasa Arab. Ia menempuh pendidikan dasar dan menengah di sebuah sekolah negeri. Pada tahun 1932 ia melanjutkan pendidikan tingginya di Universitas Khurtoum pada jurusan teknik sipil. Berkat kegigihannya dalam studi, ia dapat menyelesaikan studinya pada tahun 1936 dengan cepat, kemudian setelah lulus ia menjadi petugas kereta api, tetapi minat taha kembali fukus kepada pendidikan, ini ditandai dengan didirikannya lembaga pendidikan oleh taha pada awal tahun 1940-an. ${ }^{9}$

Selain aktif menuntut ilmu, Taha juga aktif sebagai aktivis yang tergabung dalam pergerakan nasional Sudan. Pada Oktober 1945, Taha mendirikan partai Republik (Hizb al-Jumhuri) bersama intelektual lain yang sepaham dengan pola pikirnya yang memiliki visi Islam modern-moderat. Partai tersebut awalnya bertujuan untuk melawan penjajah Inggris, ${ }^{10}$ namun kemudian berubah tujuan, yaitu untuk menyuarakan gagasan Islam moderat versi Taha, terutama ketika terjadi pro-kontra tentang perlu tidaknya Negara Islam. Kebijakan partai berkenaan dengan konfrontasi langsung dan terbuka yang ditujukan kepada penguasa kolonial Inggris yang berakibat penangkapan sekaligus penjatuhan vonis hukuman penjara terhadap Taha dan temannya pada tahun 1946. Ia dihukum penjara selama satu tahun ketika menolak untuk menarik diri dari aktivitas-aktivitas politik yang melawan pemerintah Kolonial Inggris. Namun karena mendapat protes dari partai Republik, akhirnya ia diampuni dan dibebaskan oleh

${ }^{8}$ Mahmud Muhammad Taha, Arus Balik Syari'ah, trans. by Nur Rachman (Yogyakarta: LKiS, 2003), p. 27.

9 Edward Thomas, 'Mahmud Muhammad Taha: His Life in Sudan' (Edinburgh University, 1999), pp. 77-78.

10 Taha, p. 27. 
Gubernur Jendral Inggris setelah masuk penjara selama lima puluh hari. Namun kemudian Taha kembali dipenjara selam dua tahun akibat perlawanannya terhadap kebijakan pemerintah. ${ }^{11}$

Setelah beberapa saat Taha kembali dihukum dua tahun penjara sampai pada proses pengasingan terhadap dirinya. selama masa pengasingan (khalwah), Taha mencoba merekontruksi kembali ajaran al-Qur'an sehingga muncul pemikirannya yang sangat kontroversial yang selanjutnya lebih dikenal dengan pesan kedua Islam (al-Risalah al-Tsaniayah al-Islamiyah). Buku tersebut berisi tentang ayat-ayat makiyah, meskipun berbeda sama sekali dengan angan-angan sosial yang selama ini dipahami oleh para ulama. ${ }^{12}$ Selama ini ayat makiyah dan madaniyah seolah hanya dipahami sebagai tempat pewahyuan, maka tidak demikiannya dengan apa yang digagas oleh Taha. Dalam pandangannya, ayatayat tersebut harus dimaknai sebagai teks yang berhadapan dengan realitas historis masyarakat abad ke-7 M. Ayat makiyah adalah ayatayat yang terlebih dahulu ada, ia bersifat universal, abadi, fundamental, demokratis dan anti diskriminasi. Dengan kata lain, manusia mulanya diseru untuk masuk Islam secara kaffah melalui ayat-ayat makiyah namun ketika masyarakat abad ke-7 ini gagal menjalankannya sebab situasi yang belum memungkinkan, maka mereka diserukan untuk sementara mengamalkan pesan pertama. Pesan pertama ini justru berupa ayat-ayat madaniyah yang bersifat transisional. Karena masa transisional, maka tidak mengherankan jika ayat-ayat madaniyah terkesan diskriminatif, sektarian dan kurang humanis, di antaranya seperti ayat-ayat yang berbicara tentang posisi orang-orang kafir dzimmi, ablul kitab, dan kaum perempuan. $^{13}$

Seiring berakhrinya masa pengasingan, taha mencoba aktif menulis di amajalah dan surat kabar ditempat nya tinggal dan menyampaikan Tausiah dalam rangka mengimplementasikan

${ }^{11}$ Mustaqim, Dkk, p. 12.

${ }^{12}$ Mustaqim, Dkk, p. 13.

${ }^{13}$ Mustaqim, Dkk, p. 14. 
pemikirannya. Ia sempat vakum dalam kegiatan menulis dan ceramah karena sibuk dengan pekerjaannya sebagai insinyur. Tahun 1970-an, Taha mulai aktif kembali menulis, mengajar, dan mendiskusikan pemikirannya. Di sisi lain Partai Republik semakin besar dan jumlah simpatisannya meningkat. Hal ini membuat Presiden Sudan, Numeiri, khawatir dan menganggapnya sebagai sebuah ancaman terhadap kelangsungan kekuasaannya. Akhirnya, Taha kembali ditempatkan di balik jeriji besi selama dua tahun tanpa proses hukum yang adil. Setelah taha bebas, partai Republik kembali menyampaikan kampanye penolakan terhadap proses Islamisasi di Sudan. ${ }^{14}$

Setelah Numeiri digulingkan serta pelaksanaan konstitusi transisional pada bulan Oktober 1985, kakak wanita Taha, Asma, mengajukan gugatan kepada majelis hukum besar Sudan untuk mencabut hukuman mati taha dikarenakan keberatan konstitusional serta prosedural dalam majelis hukum tersebut. Setelah itu pada bertepatan pada 18 November 1986, majelis hakim pada masa pemerintahan transisional memutuskan hukuman mati terhadap Taha dihapuskan dikarenakan kesalahan proses peradilan pada waktu itu. Buat mengenang Taha, selaku simbol untuk kebebasan demokrasi, ribuan intelektual serta handal berpartisipasi dalam ceramah universal serta dialog sepanjang satu pekan pada bulan Januari 1986. Pada dikala yang sama, Organisasi Hak Asasi Manusia Arab yang berpusat di Kairo melaporkan kalau buat menghormati Taha, bertepatan pada 18 Januari( bertepatan pada eksekusi Taha) dijadikan sebagai Hari Hak Asasi Manusia untuk bangsa Arab. ${ }^{15}$

Secara genealogis akar pemikiran Taha berasal dari pemikiranpemikiran tokoh sufi di antaranya Muhyiddin Ibn 'Arabi dalam buku Fushush al-Hikam dan Abdul Karim al-Jillin dalam buku alInsan al-Kamil. Selain itu, sebagian pemikirannya juga dipengaruhi

\footnotetext{
14 An-Naim, p. 163.

15 An-Naim, p. 163.
} 
oleh pemikiran Sigmund Freud dan Darwin. ${ }^{16}$ Kaitannya dengan pemikirannya tentang perlunya mendirikan Negara yang berideologi Islam Moderat dan mengambil bentuk Republik juga tidak bisa dilepaskan dengan situasi politik saat itu. Sudan adalah salah satu Negara Islam di benua Afrika yang selalu bergejolak.

Bersumber pada latar balik intelektualnya di atas, dikenal kalau konstruksi nalar Taha dibangun dari pemahan ilmu metodologi barat, ilmu sosial Barat, serta khazanah intelektual Islam spesialnya tasawuf. Dengan membaca karya- karyanya kita hendak mengenali kalau orientasi sufisme sangat kokoh dalam pemikiran Taha. Perihal ini normal sebab dia hidup di tengah warga Sudan yang memiliki kecenderungan Islam mistis. Di samping itu, pemikiran Taha tidak cuma seputar tentang pemikiran keagamaan, namun pula memasuki ke bermacam bidang yang lain, semacam budaya, sosial serta politik. Dalam daerah keagamaan, Taha membedakan antara syariat dengan agama(al- din). Agama, baginya, cuma satu, ialah Islam, yang tercermin dalam kalimat tauhid la ilaha illa Allah, sedangkan syariat tidak cuma satu. Maksudnya, tiap- tiap umat mempunyai syariat yang berbeda yang diakibatkan ataupun disesuaikan dengan perbandingan keahlian tiap- tiap umat tersebut. Tetapi demikian antara al- din serta syariat cuma berbeda pada tingkatan, tidak pada esensi. ${ }^{17}$

Secara akademis Taha seorang pemikir yang produktif, mengingat banyak karya yang telah ditulisnya. Salah satu buku yang mengangkat nama Taha ialah al-Risalab al-Tsaniyah min al-Islam. Menurut Abdullah al-Naim buku ini merupakan tafsir modern dan evolusioner terhadap al-Qur'an. ${ }^{18}$ Pemikiran Tafsir Taha hanya terfokus pada metodologi nasakh dan pembaharuan konsep makki dan madani. Konsep tersebut diklaim oleh Taha sebagai jalan menuju "pembaharuan Islam yang memadai" untuk membangun

${ }^{16}$ Lembaga Pengkajian dan Penelitian WAMY, Al-Mausu'ah Al-Muyassar Fi Al-Adyan Wa Al-Madrabib Al-Mu'ashirah (Riyadh: WAMY, 2008), p. 423.

${ }^{17}$ Taha, p. 181.

18 An-Naim, p. 11. 
syariat Islam yang menjunjung nilai nilai kemanusiaan sebagai sistem hukum yang sesuai secara internal dan konsisten dapat terpenuhi, sehingga masyarakat tidak memakai pemahaman konservatif dengan mempermudah proses hukum islam yang sudah ada, sehingga akan muncul permasalahan yang berat di kemudian hari.

\section{Konsep Nasakh al-Qur'an menurut Taha}

Ilmu tentang nasakh al-Qur'an sangat penting untuk dipelajari bahkan para ulama menjadikannya sebagai salah satu syarat sebelum seseorang menafsirkan al-Qur'an. Hal ini didasarkan pada satu kisah, bahwa pernah ada seseorang berbicara tentang al-Qur'an di masjid Kufah, lalu Sayyidina Ali bertanya kepadanya, "Apakah kamu mengetahui tentang ilmu nasikhmansukh?" Orang tersebut menjawab, "Tidak tahu." Maka Sayyidina Ali berkata, "Ablaka wa ablakta; kamu celaka dan membuat orang lain celaka." 19 Imam Ibn Katsir menegaskan bahwa tidak ada alasan untuk menafikan nasikh-mansukh. ${ }^{20}$ Mufasir Nusantara, M. Quraish Shihab, juga memandang pentingnya nasikh-mansukh dalam menafsirkan al-Qur'an. Ia mengatakan bahwa Allah tidak me-nasakh dalam arti membatalkan suatu hukum yang dikandung oleh satu ayat, kecuali Allah akan mendatangkan ayat lain yang mengandung hukum lain yang lebih baik atau serupa. $^{21}$

Konsep nasakh yang disepakati mayoritas ulama adalah mengganti hukum syar'i yang ada sebelumnya dengan hukum syar'i yang baru (Raf'u bukmin syar'iyyin bi dalilin syar'iyyin). Yang dimaksud mengganti hukum syar'i di sisin adalah hilangnya beban

19 Jalaluddin Al-Suyuthi, Al-Itqan Fi Ulum Al-Qur'an, trans. by Farikh Marzuki (Surabaya: Bina Ilmu, 2008), p. 85.

${ }^{20}$ Ibn Katsir, Tafsir Al-Qur'an Al-'Az̧him (Kairo: Maktabah al-Tijjariyah alKubra, 1935), I, p. 34.

${ }^{21}$ Muhammad Quraish Shihab, Wawasan Al-Qur'an: Tafsir Mawdhu'iy Atas Berbagai Persoalan Umat (Bandung: Mizan, 1996), p. 38. 
atau kesulitan manusia terhadap hukum tadi dan memberikan kemudahan dalam pelaksanaannya. ${ }^{22}$ Sebagaimana firman Allah:

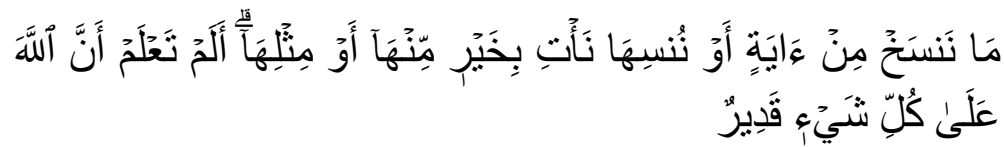

"Ayat mana saja yang Kami nasakh-kan, atau Kami jadikan (manusia) lupa kepadanya, Kami datangkan yang lebih baik dari padanya atau yang sebanding dengannya. Tidakkah kamu mengetahui bahwa sesungguhnya Allah Maha Kuasa atas segala sesuatu." (QS. Al-Baqarah [2]: 106) $)^{23}$

Berdasarkan uraian di atas dapat dipahami bahwa ayat yang turun belakangan dapat merevisi ayat yang turun sebelumnya. Apabila ayat yang turun belakangan mengganti (me-nasakb) ayat yang turun sebelumnya, maka yang muncul kemudian adalah nash tersebut lebih menitik beratkan pada kebaikan (khairiyyah) dari pada ayat sebelumnya. Di sisi lain, konsep nasakh juga tidak lepas dari diskursus makki dan madani. Karena pada umumnya, ayat yang menasakh (nasikh) adalah ayat-ayat madaniyah sementara ayat yang dinasakh (mansukh) adalah ayat-ayat makiyah.

Thaha memahami diskursus Makkiyah dan Madaniyah dengan pendangan yang berbeda dengan mayoritas ulama. menurutnya ayat-ayat Makkiyah dan ayat-ayat Madaniyah merupakan dua hal yang terpisah, yang satu dengan yang lain tidak saling terkait, bukan saja terkait perbedaan masa turunnya tetapi lebih kepada perbedaan pesan yang dibawa serta watak universalnya. Disini penulis memakai istilah Syari'ah dalam memaknai konsep Makki dan Madani

Konsep nasakh sebagaimana dijelaskan di atas berbeda dengan konsep nasakh menurut Taha. Nasakh al-Qur'an menurut Taha adalah sebuah proses perubahan hukum syariat, yaitu

22 Al-Qaththan, p. 232.

23 Departemen Agama RI, Al-Qur'an Al-Karim Dan Terjemabannya (Semarang: Toha Putra, 1996), p. 61.

TAJDID vol. 20, No. 2, Juli - Desember 2021 | 441 
perpindahan dari satu hukum ke hukum yang lain yang sesuai dengan perkembangan zaman dan nilai nilai kemanuasiaan. Dari sebuah hukum untuk mengatur kehidupan abad ke-7 dan telah diterapkan kepada hukum yang pada waktu itu terlalu maju, dan karena itu dibatalkan. Oleh karena itu, sebagai argumen, Taha memahami firman Allah QS. Al-Baqarah [2]: 106, khususnya pada penggalan ayat yang berbunyi, "Kami datangkan ayat yang lebih baik" dengan makna "membatalkan atau mencabut", dan ungkapan "atau menundanya" dengan makna "menunda pelaksanaan atau penerapannya". Lebih tegas Taha mengatakan bahwa ungkapan, "Kami datangkan yang lebih baik" artinya memakai ayat yang sesuai dengan pemahaman masyarakat dan sesuai dengan kondisi mereka ketimbang ayat yang ditunda. Sedangkan makna ungkapan "atau ayat yang sebanding dengannya" berarti mengembalikan ayat yang sama ketika waktu memungkinkan untuk menerapkannya kembali. ${ }^{24}$

Pada tataran fungsi, pandangan Taha tentang nasakh sama pendapat para ulama, Yaitu sebagai teori mengompromikan ayatayat yang bertentangan satu sama lain, dengan cara menghapuskan hukum yang di nasakh. Adapun Perbedaan Taha dengan para ulama terjadi pada proses nasakh dan hasilnya. Proses nasakh yang di apakai oleh para ulama yaitu menghapus atau menangguhkan ayat yang datang pertama/dahulu turun oleh ayat yang turun setelahnya dengan teks hukum yang sama dan berimbang dan ayat yang mansukh tidak dipakai lagi (ghair mubkam). Sementara proses nasakh dalam pandangan Taha adalah penghapusan atau penangguhan yang bersifat kondisional sesuai dengan kebutuhan. artinya ayat yang di pakai dalam menghukumi suatu kondisi menyesuaikan kebutuhan, Sedangkan ayat yang tidak relevan lagi akan di hapus, ditangguhkan dan tidak diberlakukan lagi hukumnya. Dengan demikian, nasakh dapat di artikan proses penangguhan ayat yang datang terakhir oleh ayat yang turun lebih

\footnotetext{
${ }^{24}$ Mustaqim, Dkk, p. 23.
}

442 | TAJDID vol. 20, No. 2, Juli - Desember 2021 
dahulu, atau sebaliknya, menyesuaikan dengan hukum internasional dan kondisi masyarakat modern.

Selain itu, konsep nasakh yang digagas oleh Taha ini berbeda dengan konsep nasakh yang didefinisikan oleh para ulama terdahulu, yang lebih memperhatikan waktu turunnya ayat. Tetapi dalam pandangan Taha, penghapusan itu bersifat kondisional dan masih ada ruang ijtihadi dimana terjadi penundaan sementara hingga waktu yang tepat datang untuk melaksanakan proses pembalikan nasakh). Berkenaan dengan diskursus makki dan madani, menurut Taha ayat-ayat makiyah merupakan ayat-ayat dasar yang mengandung keabadian hukum islam dan fundamental, yang menitikberatkan pada nilai keadilan pada seluruh umat manusia, tanpa membedakan keyakinan, ras, asal usul dan gender. Sementara ayat madaniyah merupakan ayat cabang yang berlaku bagi umat islam di masa Rasulullah hidup. Dan ayat cabang ini ternyata tidak relevan lagi pada zaman modern dikarnakan tidak mengandung nilai keadilan, kemanusian dan gender. Dengan demikian, ayat pokok yang tidak dipakai pada zan Nabi kembali berlaku pada abad modern ini, menjadi dasar hukum baru. Inilah yang ingin di rekontruksi taha dengan evolusi syariat yakni peralihan dari teks yang telah tercapai fungsi nya di zaman nabi ke teks lain yang tertunda utuk di aplikasikan di era modern.

Dari penjelasan di atas, dapat disimpulkan bahwa teori nasakh Al Qur'an menurut mahmud Muhammad Taha merupakan metode yang memungkinkan dilakukannya pemilihan dan pemakaian atau penundaan ayat-ayat tertentu tanpa memperhatikan waktu turunnya ayat. Pemakaian dan penundaan ayat-ayat ini didasarkan atas pertimbangan kepantasan dan kesesuaiannya dengan kebutuhan dan perkembangan zaman, Pemberlakuan hukum hanya di dasari pada tuntutan, kebutuhan, dan kemanuasian. Ketika ada kebutuhan masyarakat yang membutuhkan pelaksanaan ayat ayat makkiyah, maka ayat ayat terbut akan di terapkan, bila perlu dengan me-nasakh ayat madaniyah. Demikian sebaliknya, ketika kemaslahatan 
menghendaki pemberlakuan ayat madaniyah. Dengan demikian, bagi Mahmud Muhammad Taha pemberlakukan dan pelaksanaan ayat-ayat itu sesuai kondisi dan kontekstual. Karena itu, nasakh dalam pandangan Mahmud Muhammad Taha tidak bersifat usuli dan permanen. ${ }^{25}$

Maka berdasarkan pendapat taha tentang nasakh adalah penundaan inti dari syariat dan universal ayat-ayat makiyah, Taha ingin merekontruksi nasakh dengan membalik proses nasakh-yang umum dipahami. Pembalikan nasakh ini adalah pembatalan hukum ayat-ayat madaniyah yang sudah mapan dan hadits nabi yg berkaitan dengan ayat madaniyah, disebabkan dengan pengagungan nilai konstitusionalisme, Hukum modern, hukum Internasional, dan hak asasi manusia (HAM). Dengan demikian, jelas bahwa kriteria nasikh-mansukh adalah ayat mana yang lebih baik, bukan ayat mana yang terlebih dahulu turun.

Adapun ayat madaniyah yang tidak relevan lagi dan perlu dinasakh menurut Taha salah satunya adalah ayat tentang jihad. Aturan dasar dalam Islam adalah setiap orang bebas menjalankan kewajiban, karena bebas merupakan hak alamiah yang harus di iringi dengan penunaian kewajiban, yaitu menjalankan hak kebebasan tersebut dengan baik. Jika tidak mampu untuk menjalankan kewajiban bebasnya maka kebebasannya harus dicabut melalui hukum. ${ }^{26}$ Landasan ini yang dipakai Taha sebagai landasan utama dalam mengembalikan ayat-ayat persuasif yang terjadi di Makkah seperti:

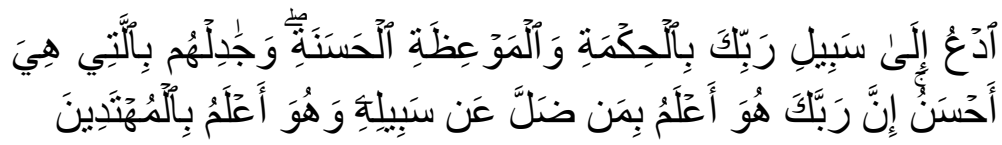

"Serulah (manusia) kepada jalan Tuhan-mu dengan hikmah dan pelajaran yang baik dan bantahlah mereka dengan cara yang baik. Sesungguhnya Tuhanmu Dialah yang lebih

\footnotetext{
${ }^{25}$ Mustaqim, Dkk, p. 23.

${ }^{26}$ Taha, p. 155.
} 
mengetahui tentang siapa yang tersesat dari jalan-Nya dan Dialah yang lebih mengetahui orang-orang yang mendapat petunjuk." 27

Berdakwah dengan metode ini berjalan selama 13 tahun, selama masa tersebut, banyak ayat yang mengandung mukjizat, melalui sekolah itu banyak tipe ideal yang dimunculkan baik dari laki-laki, perempuan maupun anak-anak. Kaum muslimin generasi awal mampu meredam dirinya dari menyakiti kaum kuffar, menghormati hak-hak sesama dan mengorbankan segala kenikmatan hidup dengan tulus dan harga diri. Menurut Taha para sarjana muslim keliru dalam memahami jihad peperangan. Menurutnya, pedang dipergunakan hanya untuk mencabut kebebasan yang digunakan secara keliru, Islam menggunakan caracara persuasif selama 13 tahun dalam menyerukan pesannya kepada individu maupun kelompok. Alasan paling mendasar dan legal mengapa Islam menggunakan pedang adalah bahwa Islam tidak mempergunakannya sebagai pisau algojo, tetapi menggunakannya sebagai pisau bedah. Maka syariat yang sekarang, sama sekali bukan tujuan Islam. Semua itu diturunkan hanya karena kondisi waktu dan disesuaikan dengan potensi kemanusiaan saja. Maka Taha Ingin menghapus ayat-ayat jihad yang merupakan ayat madaniyah, di antaranya QS. Al-Taubah [9]: 5, 14, 29 dan 36, QS. Al-Baqarah [2]: 193, dan QS. Al-Anfal [8]: 39.

Menurut penulis, pandangan Taha tentang ayat-ayat madaniyah yang berisi tentang ajaran intoleran, radikal dan cenderung menyebabkan kekerasan adalah keliru dan tidak objektif, justru Islam adalah agama yang damai serta penuh rahmat.

Oleh sebab itu, tidak terdapat tempat dalam agama Islam untuk kekerasan ataupun fanatisme dan bermacam wujud kezhaliman yang merusak kehidupan ataupun hak kepunyaan orang lain. Sehingga Islam menyangka kezhaliman yang dicoba

${ }^{27}$ RI, p. 456.

TAJDID vol. 20, No. 2, Juli - Desember 2021 | 445 
kepada seseorang manusia, sama maksudnya melaksanakan kezhaliman kepada umat manusia secara totalitas. Ini dipaparkan dalam al- Qur' an ayat madaniyah, ialah yaitu:

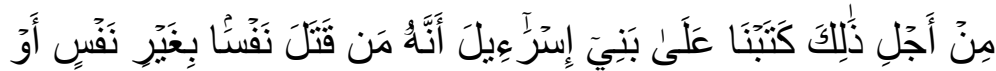

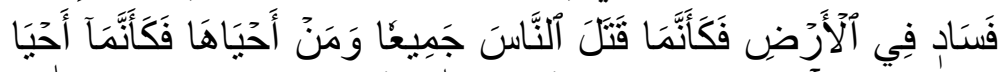

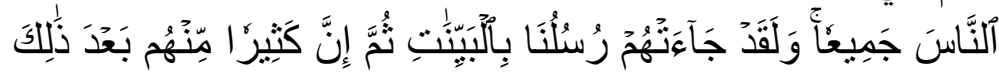

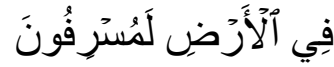

"Oleh karena itu, Kami tetapkan (suatu hukum) bagi Bani Israil, bahwa barangsiapa yang membunuh seorang manusia, bukan karena orang itu (membunuh) orang lain, atau bukan karena membuat kerusakan dimuka bumi, maka seakan-akan dia telah membunuh manusia seluruhnya. Dan barangsiapa yang memelihara kehidupan seorang manusia, maka seolaholah dia telah memelihara kehidupan manusia semuanya. Dan sesungguhnya telah datang kepada mereka rasul-rasul Kami dengan (membawa) keterangan-keterangan yang jelas, kemudian banyak diantara mereka sesudah itu sungguhsungguh melampaui batas dalam berbuat kerusakan di muka bumi." (QS. Al-Ma'idah 32)

\section{Analisis Kritis terhadap Pemikiran Taha tentang Konsep Nasakh al-Qur'an}

Jika dirunut melalui sejarahnya, pemikiran Taha berawal dari hasil kontemplasinya sewaktu berada di penjara, menurut al-Na'im basik epistem pemikiran Taha diawali dengan modern mystical approach. Menurutnya, Al-Qur'an dan Sunnah adalah sumber syariat Islam, sedangkan ijtihad merupakan upaya penafsiran terhadap alQur'an dan sunnah, bukan menambah kerangka baru terhadap alQur'an dan sunnah. ${ }^{28}$

Yang menjadi persoalan yang menjadi bahasan pokok adalah bagaimana sebuah pengetahuan dapat diukur dan diuji kebenarannya. Dalam artian bahwa, kebenaran adalah kesesuaian

\footnotetext{
${ }^{28}$ An-Naim, p. 90.
}

446 | TAJDID vol. 20, No. 2, Juli - Desember 2021 
antara apa yang diyakini dengan realitas, atau antara alam pikiran dengan hukum-hukum yang diterapkan. Dengan demikian, persoalan epistemologi dalam penafsiran al-Qur'an adalah menyangkut tolok ukur kebenaran sebuah penafsiran tersebut. Artinya, sejauh mana suatu produk penafsiran tersebut dapat dikatakan benar.

Untuk dapat mengukur suatu kebenaran tersebut, setidaknya ada dua teori yang dapat digunakan dalam menerapkan validitas konsep nasakh yang di proklamirkan oleh Taha. Kedua teori kebenaran tersebut, yaitu teori koherensi dan teori korespondensi. ${ }^{29}$

\section{Teori Koherensi}

Teori koherensi adalah suatu teori dalam menguji sesuatu pernyataan, apakah koheren ataupun tidak berubah- ubah dengan teori tersebut yang telah diandaikan kebenarannya. Teori ini melaporkan bahwa standar kebenaran itu dilandasi oleh ikatan antara komentar dengan suatu yang lain. Dengan kata lain, suatu tafsir bisa dianggap benar bila terdapat konsistensi logis dengan preposisi- preposisi yang dibentuk tadinya serta dibentuk atas asumsiyang benar cocok kenyataan serta realita.

Mengacu pada definisi teori ini, bagi penulis Taha tidak menganut teori kebenaran koherensi. Perihal ini bisa dilihat sebab Taha sudah menyalahi mayoritas Ulama tentang nasakh serta menghancurkan paradigma yang telah terbangun kalau ayat yang turun belum lama( madaniyah) me- nasakh ayat- ayat yang turun lebih dulu( makiyah). ${ }^{30}$

Nirwan Syafrin periset INSISTS menuduh kalau gagasan tersebut ingin menghancurkan islam dan masyarakatnya serta menjerumuskankan kepada kesesatan dalam memahami hukum

29 Abdul Mustaqim, Epistemologi Tafsir Kontemporer (Yogyakarta: LKiS, 2010), p. 289.

30 Zuhaili, II, p. 959.

TAJDID Vol. 20, No. 2, Juli - Desember 2021 | 447 
syariah .31 Muhammad Arkoun menilai bahwa teori ini merupakan teori yang salah, tidak bisa dipertanggung jawabkan, serta kurang realistik, .32

Serta pendapat Taha tentang ayat-ayat madaniyah yang bersifat sektarian, tidak menjunjung nilai-nilai keadilan dan terkesan menyudutkan HAM tidak teruji secara realitas dan metodologis, karena teks-teks yang turun di Madinah tidak terbukti memiliki sifat yang bertolak belakang dengan prinsip keadilan dan HAM, justru banyak ayat-ayat Madinah yang menunjung tinggi prinsip tersebut.

\section{Teori Korespondensi}

Teori korespondensi merupakan suatu teori kebenaran yang menyatakan bahwa suatu pendapat itu benar jika konten ilmu yang terkandung dalam pernyataan tersebut sesuai dengan objek yang dirujuk oleh pernyataan tersebut. Definisi lain dari Charles A. Baylis yang dikutip oleh Islah Gusmian menyatakan bahwa suatu pernyatan dikatakan benar jika terdapat suatu fakta yang memiliki kesesuaian dengan apa yang diungkapkan.33

Teori kebenaran korespondensi sebenarnya terdapat beberapa versi dan terdapat perbedaan asumsi antara satu sama lain. Seperti teori korespondensi versi Leibniz yang mendasarkan diri pada asumsi adanya keselarasan yang sudah ditetapkan terlebih dahulu oleh Tuhan (pre-established harmony) antara tatanan pengetahuan dan kenyataan. Kemudian teori korespondensi Wittgenstein dan kaum atomis logis mendasarkan diri pada asumsi bahwa struktur bahasa secara isomorfis (berhubungan satu sama lain) dengan struktur dunia. Dengan kata lain bahasa menggambarkan kenyataan (language pictures reality). Sedangkan teori korespondensi Thomas Aquinas dan kaum Skolastik

31 Nirwan Syafrin, http://insists.id

32 An-Naim, p. 114.

33 Islah Gusmian, Khazanah Tafsir Indonesia (Yogyakarta: LKiS, 2013), p. 123.

448| TAJDID vol. 20, No. 2, Juli - Desember 2021 
mendasarkan diri pada asumsi bahwa adanya keselarasan antara akal budi dan kenyataan. Dari penjelasan tersebut dapat ditarik kesimpulan bahwa ketiga versi kebenaran korespondensi di atas menyatakan bahwa harus ada kesesuaian antara pikiran atau pernyataan dengan kenyataan empiris. Jika dibawa ke ranah tafsir, maka dapat dikatakan bahwa tolok ukur kebenaran sebuah tafsir dalam perspektif teori kebenaran ini adalah sejauh mana kesesuain tersebut memiliki kesesuaian dengan realitas empiris.34

Mengacu pada teori ini, Taha mendapatkan konsep tersebut dengan menggunakan pendekatan sufistik, Taha memperoleh kasyf. Metode ini memiliki ciri kontemplatif, menunjukkan keadaan sadar yang lebih besar untuk mengakui universalitas pengalaman keberagaman yang otentik. Hal ini tampak sekali dalam ide the second of massage. Untuk mendapatkan hal ini Taha melakukan ibadah yang sungguh-sungguh, berpuasa dan meditasi. Dengan demikian, epistemologis Taha dapat dikategorikan epistemology 'irfani (illuminatif).

Hasil pemahaman Taha tentang al-Qur'an yang diperoleh melalui kasyf kemudian diabstraksikan sehingga menjadi konsep yang dapat dipahami secara rasional. Oleh sebab itu, penulis cenderung untuk menyebut model epistemologi Taha sebenarnya juga perpaduan antara epistemology 'irfani-burhani, yakni model berfikir yang berangkat dari illuminasi yang bersifat demonstratiffilosofis.

Menurut penulis model pengetahuan yang diperoleh melalui kasyf cenderung bersifat subjektif sebab sulit membuktikan bahwa Taha benar-benar memperoleh kasyf dalam tradisi penafsiran. Model tafsir seperti itu biasanya banyak dilakukan oleh kaum sufi. Sementara itu ada pula yang berkata bahwa tafsir sufi adalah "Tafsir yang didasarkan pada upaya menelisik makna dari kata-kata yang samar, baik ketika kata-kata itu berdiri sendiri maupun setelah tersusun dalam sebuah kalimat, tanpa terpaku pada makna lahir

${ }^{34}$ Mustaqim, p. 293.

TAJDID Vol. 20, No. 2, Juli - Desember 2021 
yang biasa dipahami atau makna leksikal.” Dalam pandangan tafsir sufi ingin menegaskan bahwa al-Qur'an memiliki mutiara makna yang sangat dalam, tetapi sangat sulit dipahami secara biasa atau sesuai makna lahir semata melalui struktur bahasa.

Bahwa teks tidak bisa mewakili seluruh ide dan gagasan penulisnya, karena ide-ide itu seringkali tak terbatas, sementara teks itu terbatas karena ia terdiri dari huruf-huruf yang terbatas. Oleh karena itu, cara terbaik adalah mengonfirmasi maksud suatu teks kepada pengarangnya yakni Tuhan melalui mujahadah, sehingga mendapat kasyf. ${ }^{35}$

Para ulama tidak dapat menerima tafsir seperti itu manakala tidak memenuhi syarat sebagai berikut:

a) Penafsiran tersebut harus sesuai dengan waktu dan tempat diturunkanny ayat.

b) Pemaknaan harus secara inheren dan tepat.

c) Adanya munasabah antara tafsiran dan lafaz ayat yang di ditafsirkan sehingga terbentuk suatu hubungan yang konprehensif.

d) Tafsir tersebut tidak bertentangan dengan akal pemikiran manusia dan hukum islam secara umum.

Penulis melihat bahwa konsep Taha tidak menganut teori korespondensi ini karena beliau mendapatkan pemikirannya tersebut pada saat dibuang dari negaranya, bukan melalui penelitian secara empirik dan tidak bisa dipertanggungjawabkan secara teori, serta metode yang ditawarkan sangat bertentangan dengan hukum yang sudah lama selesai dan komprehensif.

Berdasarkan pada teori koherensi dan korespondensi yang telah dipaparkan sebelumnya maka dapat disimpulkan bahwa metode yang dipakai oleh Taha sulit dipertanggung- jawabkan secara epistemologis. Karena metode tersebut ditemukan pada saat di asingkan dari negaranya tidak melalui penelitian secara empirik.

35 Taha, p. 98.

450 | TAJDID vol. 20, No. 2, Juli - Desember 2021 
Sebagaimana di tulis dalam bukunya ar risalah at tsaniyyah, taha mengatakan bahwa seolah-olah memperoleh ilham dari allah untuk membuat perubahan dan pembaharuan hukum islam melaui teori Nasakh Al Qur'an yang oleh Taha dipahami sebagai penangguhan kembali ayat-ayat madaniyah dan pemberlakuan kembali ayat-ayat makiyah. ${ }^{36}$

Mengenai konsep nasakh al-Qur'an, Taha memandang bahwa teks-teks makiyah lebih bersifat universal, egaliter dan humanis serta menjunjung tinggi nilai hak asasi manusia dibanding dengan dengan ayat-ayat yang bersifat madaniyah. Pandangannya itu sangat kontras dibandingkan dengan pandangan-pandangan yang telah muncul terlebih dahulu. Di mana pandangan didasarkan pada HAM yang di gaungkan oleh barat dibanding pada persoalan yang terkandung dalam al-Qur'an itu sendiri. Mayoritas Ulama memahami dan menympaikan tentang teori nasakh Al Qur'an sebagai teori penghapusan, penggantian hukum dari ayat tersebut sebagaimana disampaikan dalam QS. Al-Baqarah ayat 106. Ayat tersebut sama-sama dijadikan landasan baik oleh mayoritas ulama dan oleh Taha sendiri. mereka memahami ungkapan "nunsiba" sebagai penghapusan atau penggantian dari hukum tersebut, bukan yang lain.

Akan tetapi maksud pengapusan oleh mayoritas ulama diterjemahkan kembali oleh Taha sebagai penghapusan ayat-ayat madaniyah terhadap ayat-ayat makiyah. Padahal mayoritas ulama tidak pernah ditemukan pendapat yang mengatakan bahwa bahwa nasakh adalah penghapusan ayat-ayat madaniyah terhadap ayat-ayat makiyah melainkan penghapusan yang dilakukan oleh ayat yag datangnya kemudian terhadap ayat yang datangnya lebih dahulu yang keduanya bertentangan dengan konteks waktu dan tempat berbeda pula dalam hal hukum. ${ }^{37}$

\footnotetext{
36 Taha, pp. 30-31.

37 Taha, p. 56.
} 
Mahmud Muhammad Taha kurang memahami ketika memberikan kritik terhadap pemikiran salafussholih dan menyamakan status bahwa semua ayat makiyah dihapus oleh ayat madaniyah. Padahal menurut mayoritas ulama hanya segelintir ayat saja yang dihapus. Dalam buku nya Al-Zarkasy berpendapat bahwa nasakh hukum yang bacaannya masih ada dan tertulis di al Qur'an hanya terdapat dalam beberapa surah. Dan hanya pada ayat ayat tertentu saja yang mengalami proses nasakh tersebut.

Penulis memahami bahwa inti dari metode taha dalam memahami Tujuan hukum yang terkandung dalam al-Qur'an bukan didasarkan pada teks al-Qur'an. Maka pemikiran ini pernah juga di lakukan di kalangan umat Islam, sebagaimana pada masa khalifah ke 2 Umar bin Khattab pernah menentukan suatu hukum berdasarkan pada pesan yang terkandung dalam al-Qur'an. Misalnya, pada waktu khalifah ke 2 Umar bin Khattab dihadapkan pada persoalan qishos bagi seorang pencuri. Di mana dalam keputusan kasus tersebut, Umar tidak melakukan hukum qishos pada pencuri tersebut akan tetapi membebaskan pencuri tersebut dengan dasar nilai kemanusiaan dan hak asasi manusia.

Keputusan yang di ambil oleh Umar bin Khattab, berdasarkan pada prinsip hak asasi manusia yang harus di tegakkan oleh Khalifah terhadap pencuri tersebut. pada zaman Umar bin Khattab belum muncul kasus HAM, jika kembali pada konteks kekinian, maka dapat disimpulkan pemikiran Umar lebih didasarkan pada persoalan HAM.

Adapun problem ketika menganalisis pemikiran Taha terletak pada persoalan metodologis, ada 3 masalah yang perlu di analisis; pertama, berkaitan dengan metodologi sufistik. Metodologi Taha tersebut sangat sulit untuk di laksanakan dan dipertanggungjawabkan secara epistimologis karena metodologi yang taha sampaikan tidak bisa diverifikasi dengan baik. Apakah benar dari Allah dan allah memberikan "ilham" pada Taha, agar al- 
Qur'an dan hadis dipahami dengan second message? Seperti apa ukurannya?

Kedua, permasalahan teori nasakh versi taha. Dalam teori nya, Taha menggunakan ide nya dengan data yang tidak tepat cenderung menyimpang, taha menilai teori hukum klasik atau ayat madaniyah dihapus oleh ayat makiyah. Pandangan taha tentang perbaharuan teori nasakh ini perlu diklarifikasi dan di analisis dengan baik dan benar sesuai dengan keadaan, dimana data tersebut tidak didukung dengan fakta ilmiah. Sejak kapan ada ketentuan ayat madaniyah menghapus ayat makiyah? Bahkan dalam ilmu Ushul al-Fiqh, ayat madaniyah tidak menghapus ayat makiyah melainkan men-takhshish ayat makiyah. ${ }^{38}$

Perbedaan menghapus dan men-takhshish sangatlah jauh perbedaan nya. Menghapus berarti ayat yang dihapus tidak berlaku lagi hukumnya, sedangkan takhshis berarti ayat yang di- takhshish masih diangap berlaku. ${ }^{39}$ Di samping itu, dalam ilmu Ushul al-Fiqh, nasakh hanya dipakai sebagai penengah apabila ada dua dalil yang bertentangan tanpa bisa dikompromikan. Ayat makiyah dan ayat madaniyah. ${ }^{40}$ Oleh karena itu, dianggap bahwa kedua kelompok ayat itu telah terjadi proses nasakh adalah sikap yang kurang memiliki argumentasi yang valid.

Ketiga, tentang kategori pendapat aneh dan menyimpang. Dengan kata lain, pendapat Taha ini dapat dikategorikan sebagai teori yang syadz, ganjil, jarang, dan diragukan, karena pernyataan itu bertentangan dengan pandangan mayoritas ulama dalam memahami konsep ayat makiyah dan ayat madaniyah dengan menggunakan ilmu nasakh Al Qur'an. ${ }^{41}$

38 Abu Hamid Al-Ghazali, Al-Mustashfa Min 'Ilm Al-Ushul (Kairo: Maktabah al-Jayyidah), p. 71.

39 Al-Qaththan, p. 227.

${ }^{40}$ Muhammad Wafa, Ta'arudh Al-Adillah Al-Syar'iyyah Min Al-Kitab Wa AlSunnah Wa Al-Tarjih Bainaha (Kairo: Al-Muttanabi, 1992), p. 8.

${ }^{41}$ Wafa, p. 14. 


\section{Penutup}

Berdasarkan penjelasan dan analisis yang di paparkan, maka dapat disimpulkan bahwa pemahaman Mahmud Muhammad Taha tentang konsep nasakh berbeda dengan pemahaman para ulama pada umumnya dan cenderung menyesatkan. Perbedaan tersebut diawali dari pemahamannya tentang konsep makki dan madani di mana yang pertama merupakan ayat pokok (ushul) sementara yang kedua adalah ayat cabang (furu). Sehingga menurutnya, ayat madaniyah yang merupakan cabang hukum dan hanya diterapkan sementara harus di-nasakh dengan ayat makiyah yang merupakan pokok dan memuat tentang nilai-nilai fundamental seperti keadilan, kesetaraan, toleransi, demokrasi, Gender dan sseuai dengan nilai nilai hak asasi manusia, sehingga harus diterapkan hukum nya kembali di era sekarang ini. Namun, konsep nasakh yang dikembangkan oleh Taha tersebut masih terdapat sejumlah permasalahan epistemologis dan sulit di verivikasi kebenarannya.

\section{Daftar Pustaka}

Al-Ghazali, Abu Hamid, Al-Mustashfa Min 'Ilm Al-Ushul (Kairo: Maktabah al-Jayyidah)

Al-Qaththan, Manna', Mabahits Fi 'Ulum Al-Qur'an (Beirut: Dar alFikr, 1990)

Al-Suyuthi, Jalaluddin, Al-Itgan Fi Ulum Al-Qur'an, trans. by Farikh Marzuki (Surabaya: Bina Ilmu, 2008)

Al-Thabari, Ibn Jarir, Tafsir Al-Thabari (Madinah: Badr Hijr, 1886), VII

An-Naim, Abdullah Ahmad, Dekonstruksi Syari'ab: Wacana Kebebasan Sipil, Hak Asasi Manusia Dan Hubungan Internasional Dalam Islam, trans. by Amiruddin Arrani Ahmad Suaedy (Yogyakarta: LKiS, 2012)

Gusmian, Islah, Khazanah Tafsir Indonesia (Yogyakarta: LKiS, 2013)

Katsir, Ibn, Tafsir Al-Qur'an Al-'Azbim (Kairo: Maktabah alTijjariyah al-Kubra, 1935), I

454 | TAJDID vol. 20, No. 2, Juli - Desember 2021 
Mustaqim, Abdul, Epistemologi Tafsir Kontemporer (Yogyakarta: LKiS, 2010)

Mustaqim, Abdul, and Dkk, Melibat Kembali Studi Al-Qur'an: Gagasan, Isu Dan Tren Terkini (Yogyakarta: Idea Press, 2015)

Qardhawi, Yusuf, Al-Qur'an Berbicara Tentang Akal Dan Ilmu Pengetahuan, trans. by Irfan Salim (Jakarta: Gema Insani, 1998)

RI, Departemen Agama, Al-Qur'an Al-Karim Dan Terjemahannya (Semarang: Toha Putra, 1996)

Shihab, Muhammad Quraish, Ayat-Ayat Fitnah (Jakarta: Lentera Hati, 2008)

—., Wawasan Al-Qur'an: Tafsir Mawdhu'iy Atas Berbagai Persoalan Umat (Bandung: Mizan, 1996)

Taha, Mahmud Muhammad, Arus Balik Syariah, trans. by Nur Rachman (Yogyakarta: LKiS, 2003)

Thomas, Edward, 'Mahmud Muhammad Taha: His Life in Sudan' (Edinburgh University, 1999)

Wafa, Muhammad, Ta'arudh Al-Adillah Al-Syar'iyyah Min Al-Kitab $W a$ Al-Sunnab $W a$ Al-Tariih Bainaha (Kairo: Al-Muttanabi, 1992)

WAMY, Lembaga Pengkajian dan Penelitian, Al-Mausu'ah AlMuyassar Fi Al-Adyan Wa Al-Madzahib Al-Mu'ashirah (Riyadh: WAMY, 2008)

Zuhaili, Wahbah, Ushul Al-Figh Al-Islami (Beirut: Dar al-Fikr, 2001), II 